Vol 4 No 1 Tahun 2019(40-51) Jurnal Terapan Ilmu Keolahragaan
http://ejournal.upi.edu/index.php/JTIKOR/

\title{
Evaluasi Program Pembinaan Pelatihan Daerah (Pelatda) Cabang Olahraga Shorinji Provinsi NTT Tahun 2016
}

\author{
Anna Yunita Gelu \\ Pascasarjana Uiversitas Negeri Jakarta, Indonesia
}

\begin{abstract}
Abstrak
Kata Kunci:

Evaluasi Program PELATDA, Shorinji Kempo Provinsi NTT

Penelitian ini bertujuan untuk mengetahui atau memperoleh gambaran mengenai pelaksanaan program pembinaan Pelatihan Daerah (PELATDA) Cabang Olahraga Shorinji Kempo Provinsi NTT dalam menghadapi Pekan Olahraga Nasional ke XIX tahun 2016 di Jawa Barat. Penelitian ini menggunakan model evaluasi CIPP dari Stufflebeam, dengan menggunakan pendekatan kualitatif dan pendekatan kuantitatif. Tehnik analisa data yang digunakan adalah statistik deskriptif. Subyek dalam penelitian adalah Kabid Binpres PERKEMI NTT, Pelatih dan Atlet. Instrumen yang digunakan dalam pengumpulan data adalah wawancara, angket, studi dokumentasi. Hasil penelitian menunjukkan bahwa tahapan context pelaksanaan program pembinaan PELATDA mempunyai dasar hukum yang jelas dengan tujuan meraih prestasi di PON, pada tahapan input memperoleh persentase $78,85 \%$, tahapan process memperoleh presentase $87,83 \%$ dan tahapan product memperoleh presentase sebesar 87,67\%.Dengan hasil penelitian ini diharapkan cabang olahraga Shorinji Kempo NTT untuk terus melakukan perbaikan-perbaikan guna pencapaian prestasi yang tertinggi baik nasional maupun internasional.
\end{abstract}

\begin{abstract}
The purpose of this reseach how to describe implementation of performance constrution east nusa tenggara Shorinji Kempo to be ready at preperation national olimpic games XIX 2016 in West Java. The method of this study use descriptive evaluative method using CIPP reseach (context, input, process, product). By using a qualitative approach and quantitative approach to data analisys tecnique data is descriptive statistic. Subjek of the research are head of sport performance, coach and athlete. Data collection tecnique was obtanied and questioners interview, observation, and documentation. The results showed that the variables of context explain that the coaching and exercise areas (PELATDA) based on legal bassis and to reach achievment in PON, input variable the precentage 78,85 , process evaluation the precentage 87,83 and product evalution the precentage $87,67 \%$. The reseach of result be expected for Shorinji Kempo East Nusa Tenggara forward to reaching out the best performence not only natioanal or internatioanal.
\end{abstract}

(C) 2019 Universitas Pendidikan Indonesia

Alamat korespondensi:
Uiversitas Negeri Jakarta, Jakarta
E-mail: yunitagelu07@yahoo.co.id eISSN: 2549-6360 


\section{PENDAHULUAN}

Perkembangan dan kemajuan bangsa Indonesia terjadi di semua bidang salah satunya di bidang olahraga sehingga pemerintah telah mencanangkan program "memasyarakatkan olahraga dan mengolahragakan masyarakat", dalam hal ini masyarakat dapat memilih dan melakukan olahraga apapun yang disukai baik itu olahraga untuk kesehatan dan bahkan untuk prestasi.

Shorinji Kempo merupakan salah satu cabang olahraga prestasi yang ada di Indonesia dan diminati masyarakat, hal ini terlihat dari jumlah peserta yang berpartisipasi dalam setiap kejuaraan baik di tingkat daerah maupun nasional. Shorinji Kempo dipertandingkan secara perorangan, pasangan dan beregu baik untuk nomor pertandingan seni (embu) maupun perkelahian terbatas (randori). Cabang olahraga Shorinji Kempo telah berkembang di berbagai wilayah di Indonesia salah satunya di Provinsi Nusa Tenggara Timur (NTT).

Shorinji Kempo Provinsi NTT dibawa oleh Barnabas nDjurumana (alm) dan telah membentuk pengurus Daerah, Cabang dan bahkan terdapat perkumpulan-perkumpulan yang telah menyebar di semua wilayah NTT. Shorinji Kempo NTT juga aktif dalam berbagai macama kejuaraan yang ada dalam agenda kegiatan PB PERKEMI baik itu kejuaraan nasional antar kota, kejuaraan nasional mahasiswa, PraPON dan PON.

Pekan Olahraga Nasional (PON) menjadi tolak ukur kemajuan daerah dalam prestasi olahraga karena dapat terlihat tingkat keberhasilan yang telah dicapai suatu daerah dan dapat mengetahui sejauh mana proses pembinaan yang telah dilaksanakan.

Pada PON XVII tahun 2008 di Kalimantan Timur dan PON XVIII tahun 2012 di Riau cabang olahraga Shorinji Kempo NTT tidak mengalami peningkatan prestasi yaitu hanya meraih dua medali emas, hal ini membuat Pengprov PERKEMI NTT berusaha keras untuk terus membenahi diri dan terus mempersiapkan diri dalam rangka menghadapi kejuaraan selanjutnya termasuk PON dengan lebih baik.

Pencapaian prestasi olahraga harus didukung dengan pembinaan yang baik dan terencana agar mencapai prestasi maksimal.
Undang-undang Republik Indonesia Nomor 3 Tahun 2005, tentang Sistem Keolahragaa Nasional Bab VII pasal 27 ayat 1 berbunyi, "Pembinaan dan pengembangan olahraga prestasi dilaksanakan dan diarahkan untuk mencapai prestasi olahraga pada tingkat daerah, nasional dan internasional".

Selanjutnya Pembinaan menurut Miftah Toha adalah suatu tindakan, proses, hasil atau pernyataan menjadi lebih baik. ${ }^{2}$

Dengan pembinaan yang baik dimaksudkan agar prestasi dapat terus meningkat dan bisa dipertahankan. Pencapaian prestasi yang optimal memerlukan pola pembinaan yang baik dan berkelanjutan.

Pola pembinaan yang baik harus mempunyai dasar dan tujuan pelaksanaan yang jelas dan terarah sehingga menjadi dasar untuk pelaksanaan pembinaan. Faktor lain yang mempengaruhi pembinaan yaitu perekrutan atlet maupun pelatih, anggaran, sarana dan prasarana, serta penjadwalan program latihan. Dalam proses pembinaan harus memperhatikan pelaksanaan jadwal latihan dan keefektifan program latihan. Bila semua faktor tersebut telah terpenuhi maka pencapaian prestasi akan menjadi lebih maksimal.

Perekrutan atlet harus mempunyai standar pemilihan yang jelas sehingga atlet yang diseleksi memiliki kualitas yang sangat baik sehingga prestasi yang diraih akan semakin maksimal. Proses perekrutan tidak hanya pada atlet saja tetapi pelatih juga harus melewati tahapan seleksi agar mendapatkan pelatih yang kompeten sehingga dapat mencapai target yang telah ditetapkan.

Pelatihan yang baik harus didukung oleh penjadwalan program latihan yang terencana dengan baik dan ketersediaan sarana dan prasarana yang memadai dapat menunjang keberhasilan latihan. Selanjutnya program latihan yang terencana dengan baik akan berdampak pada pelaksaan dan

${ }^{1}$ Undang-undang Nomor 3 Tahun 2005 tentang Sistem Keolahragaan Nasional, Kementerian Pemuda dan Olahraga Republik Indonesia, h. 20

2 Miftah Toha, Ilmu Administrasi Publik Kontemporer (jakarta : Kencana Prenada Media Group, 2010), h. 207 
memberikan peningkatan yang signifikan dalam proses latihan sehingga dapat menghasilkan prestasi yang maksimal.

Sukses di berbagai arena pada umumnya merupakan hasil dari perencanaan, kerja keras, komitmen, dan program latihan yang benar". 3

Pencapaian yang optimal sangat memerlukan pola pembinaan yang baik dengan didukung oleh semua unsur yang terkait sehingga pencapaian prestasi yang akan diraih dapat terlaksana dengan maksimal.

Berdasarkan penjelasan diatas peneliti tertarik untuk melakukan penelitian tentang evaluasi program pembinaan pelatihan daerah (PELATDA) cabang olahraga Shorinji Kempo NTT tahun 2016.

\section{Evaluasi Program}

Makna evaluasi program yang dikemukakan oleh dua orang ahli evaluasi, yaitu Cronbach dan Stufflebeam, yang dikutip oleh Arikunto, Abdul Jabar adalah : "upaya menyediakan informasi untuk disampaikan kepada pengambil keputusan.Evaluasi program dapat membantu menilai seberapa besar program tersebut telah berjalan, dan sekaligus sebagai bahan pertimbangan kedepannya.

Ralph Tyler dalam Suharsimi mendefinisikan bahwa evaluasi program adalah "proses untuk mengetahui apakah tujuan program sudah dapat terealisasikan". 4

Evaluasi program menurut Saburi Musa adalah "suatu kegiatan untuk memperoleh gambaran tentang keadaan suatu objek secara terencana, sistematik dan arah tujuan yang jelas". 5

Berdasarkan beberapa penjelasan tentang evaluasi program dapat ditarik kesimpulan bahwa evaluasi program adalah kegiatan mengumpulkan, menyusun dan

3 James Tangkudung, KEPELATIHAN OLAHRAGA "Pembinaan Prestasi Olahraga" (Jakarta : Cerdas Jaya, 2006), h. 8

4 Suharsimi Arikunto dan Cepi Safruddin Abdul Jabar, Op. Cit., h. 5.

5 Saburi Musa, Evaluasi Program Pembelajaran dan Pemberdayaan Masyarakat (Bandung: Y.Pin. Indonesia, 2005), h. 7 mengolah informasi serta menganalisanya, tentang bekerja atau tidaknya suatu program atau sejauhmana program tersebut telah tercapai, sehingga bisa diketahui bila terdapat perbedaan antara rencana yang telah ditetapkan dengan hasil yang bisa dicapai, selanjutnya informasi tersebut digunakan untuk menentukkan alternatif atau pilihan yang tepat dalam mengambil sebuah keputusan.

\section{METODE}

Metode dan desain penelitian yang digunakan dalam penelitian ini ialah metode deskriptif kualitatif. Metode penelitian deskriptif dirancang untuk mengumpulkan informasi tentang keadaan-keadaan nyata sekarang, tujuan dari penelitian deskriptif adalah membuat gambaran secara sistematis, faktual dan akurat mengenai fakta-fakta dan sifat-sifat populasi atau wilayah penelitian tertentu.

Penelitian evaluatif ini menggunakan model Context Input Process Produk (CIPP) dari Stufflebeam yang diyakini dapat mengidentifikasikan seluruh komponen mengenai Program Pembinaan PELATDA Sorinji Kempo NTT yang dimulai dari dasar pelasanaan, persiapan sampai dengan hasil, komponen yang diperoleh menjadi bagian dari pelaksanaan evaluasi ini.

Context dalam penelitian ini menitikberatkan pada dasar pelaksaan program PELATDA Cabang olahraga Shorinji Kempo NTT, pada tahapan Input fokus pada: perekrutan pelatih, perekrutan atlet, sarana dan prasarana, pendanaan dan penjadwalan program latihan, untuk tahapan Proses meliputi pelaksanaan program latihan dan keefektifan pelaksanaan program latihan, dan pada tahapan Product melihat dampak pelaksanaan program pembinaan PELATDA cabang olahraga Shorinji Kempo.

Penelitian ini dilakukan melalui beberapa kegiatan pengumpulan data, yaitu: observasi, wawancara, kuisioner dan studi dokumentasi.

Dalam kegiatan pengumpulan data menggunakan jenis-jenis instrument penelitian yang sesuai dengan kebutuhan 
menurut karakteristik data serta kesempatan peneliti untuk menggunakannya.

Penelitian evaluatif terhadap program pembinaan Shorinji Kempo dilaksanakan di Kota Kupang Provinsi Nusa Tenggara Timur (NTT). Waktu penelitian mulai dari bulan April hingga bulan Desember 2017. Pada penelitian ini subyek penelitian adalah para pihak yang terlibat dalam pelaksanaan program yaitu Kabid Binpres PERKEMI NTT, Pelatih dan Atlet.

Analisis data kualitatif selama di lapangan menggunakan analisis data deskriptif . "Analisis data terdiri beberapa komponen yang saling berinteraksi, yaitu reduksi data (data reduction), penyajian data (data display), dan penarikan kesimpulan atau verifikasi (drawing/verifying)" ${ }^{6}$

\section{HASIL DAN PEMBAHASAN}

Berdasarkan data yang diperoleh melalui wawancara, kuisioner, observasi dan studi dokumentasi oleh peneliti mengenai Program Pembinaan Pelatihan Daerah (PELATDA) Shorinji Kempo NTT diperoleh hasil sebagai berikut :

\section{Evaluasi Konteks (Context)}

Hasil evaluasi Konteks Program Pembinaan PELATDA Cabang olahraga Shorinji Kempo NTT secara umum sudah mempunyai dasar pelaksanaan yang jelas dan tujuan program pelaksanaan PELATDA yang terarah sehingga dijadikan acuan dalam pelaksanaan pembinaan untuk meningkatkan prestasi Shorinji Kempo NTT pada PON XIX tahun 2016 di Jawa Barat.

\section{a. Dasar Pelaksanaan PELATDA}

Dasar pelaskanaan program pembinaan PELATDA PON NTT cabang olahraga Shorinji Kempo sudah jelas dan mempunyai kekuatan hukum, terbukti dari hasil wawancara dengan Ketua BINPRES PERKEMI NTT yang menyatakan bahwa dasar pelaksanaan PELATDA PON berdasarkan pada hasil PRAPON dan diperkuat dengan SK KETUA UMUM KONI NTT Nomor 04 Tahun 2016 tanggal 27 Januari 2016 tentang Pemusatan Latihan

${ }^{6}$ Sugiyono, op. cit., h. 337-338
Daerah (PELATDA) PON XIX/2016 Jawa Barat.

\section{b. Tujuan Program Pembinaan PELATDA}

Tujuan program pembinaan juga sudah dibuat berkelanjutan sesuai dengan kebutuhan PERKEMI NTT yang dimulai dari Prapon 2015 sampai dengan PON 2016 yaitu mempersiapkan atlet NTT dengan maksimal sehingga dapat meningkatkan prestasi dan mengangkat harkat dan martabat daerah di tingkat nasioanal (PON). Selain itu memberikan kesempatan kepada pelatih untuk menciptakan juara PON dan mendukung program kerja KONI NTT tentang pembinaan prestasi khususnya pada PON.

\section{c. Evaluasi Masukan (Input)}

Tahapan evaluasi Input mempunyai beberapa faktor yang mempengaruhi pelaksanaan program pembinanaan Pelatihan Daerah (PELATDA) PERKEMI NTT diantaranya tentang perekrutan pelatih, perekrutan atlet, pendanaan, sarana dan prasarana, dan penjadwalan program latihan.

\section{1) Perekrutan pelatih}

Perekrutan pelatih PELATDA cabang olahraga Shorinji Kempo NTT berdasarkan prestasi khususnya pernah menjuarai PON karena asumsi yg dibangun adalah bahwa pelatih sudah pernah merasakan bagaimana menjadi juara sehingga harus mengetahui bagaimana menciptakan atlet yg bisa menjadi juara atau bisa juga dikembangkan bahwa atlet tersebut menjadi juara dengan nilai dan kualitas yang lebih baik.

Itulah alasan prinsip Shorinji Kempo NTT selalu melibatkan mantan atlet yang sudah pernah menjadi juara khususnya peraih medali emas PON untuk menangani atletatlet yang akan mengikuti kompetisi ditingkat nasional. Selanjutnya pelatih tersebut harus mempunyai tempat latihan sendiri (dojo) sebagai bukti penerapan ilmu Shorinji Kempo dan dilihat juga keaktifan pelatih tersebut dalam kegiatan Shorinji Kempo.

Untuk pemahamaham program latihan PELATDA pelatih-pelatih yang direkrut wajib menjalani proses latihan selama 12 hari oleh pendiri Shorinji Kempo NTT Senpai Barnabas nDjurumana (alm) dengan tujuan agar dapat memahami tujuan dari program 
yang akan diberikan kepada atlet sehingga

siap melaksanakan TC PON 2016.

\section{2) Perekrutan Atlet}

Tabel Persentase Perekrutan Atlet

\begin{tabular}{|c|c|c|c|c|c|}
\hline NO & Subyek & Score Hasil & Skor Max. & \% & Kriteria \\
\hline 1 & Atlet & 463 & 600 & 77,17 & Baik \\
\hline
\end{tabular}

Hasil angket pada Evaluasi Masukan (Input) komponen perekrutan atlet Shorinji Kempo NTT dengan 5 pernyataan angket menggunakan skala Likert yang diberikan kepada 24 atlet menunjukkan persentase
77,17\% dengan kategori baik dalam kriteria keberhasilan program.

Berdasarkan data diatas dapat digambarkan ketercapaian perekrutan atlet dalam bentuk diagram :

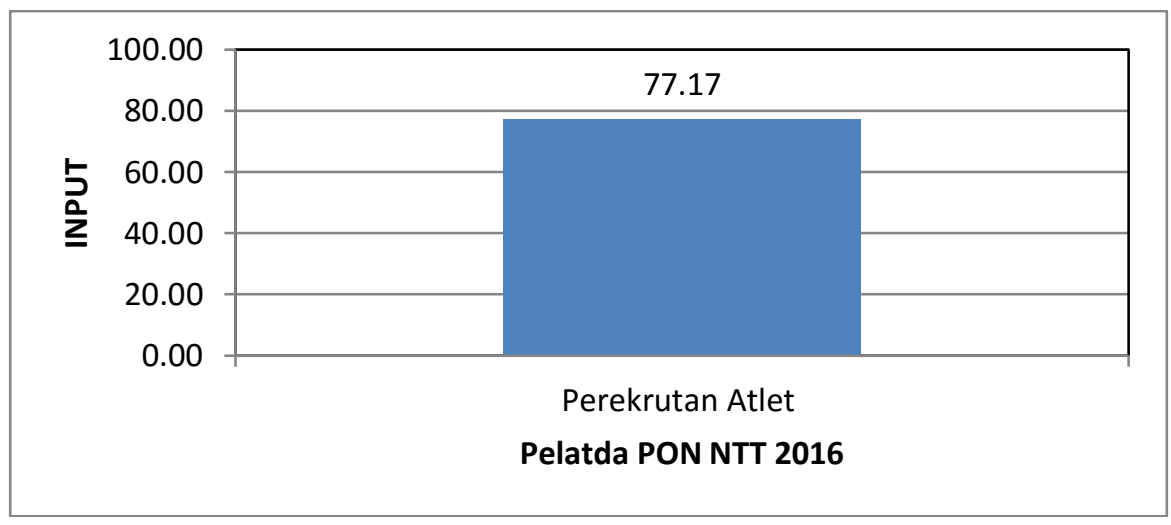

Diagram Komponen Perekrutan Atlet

Atlet yang dipilih dalam pembinaan PELATDA Shorinji Kempo NTT berdasarkan prestasi, test kesehatan dan karakter/sikap atlet. Pada pelaksanaannya sudah dijalankan, dimana atlet diseleksi berdasarkan prestasi yang dimulai dari kejuaraan daerah, kemudian mengikuti test kesehatan dan selama proses persiapan pertandingan atlet selalu dinilai sikap dan kesiapan mentalnya sehingga dapat meraih prestasi di PON XIX. Berbagai macam indikator yang diterapkan bertujuan agar atlet yang mewakili Shorinji Kempo NTT memiliki kapasitas dan kompetensi yg diharapkan bisa memperoleh medali baik medali emas, medali perak dan medali perungggu di event yg akan diikuti.

\section{3) Pendanaan}

Pelaksanaan program pembinaan

PELATDA PON XIX cabang olahraga

\section{4) Sarana dan Prasarana}

khususnya cabang olahraga Shorinji Kempo dibiayai oleh KONI NTT yang bersumber dari bantuan Hibah Pemerintah Provinsi NTT Tahun anggaran 2016 dan usaha lain yang sah dan tidak mengikut.

Anggaran dari KONI tidak dapat diandalkan sepenuhnya karena keterbatasan anggaran yang dimilki sehingga terjadi kekurangan untuk memenuhi kebutuhan pembinaan pada PERKEMI NTT, hal ini membuat Pengprov PERKEMI NTT tidak hanya fokus pada persiapan dan prestasi PON tetapi juga berusaha mencari tambahan dana demi menutupi kekurangan yang ada pada pelaksanaan PELATDA. Keterbatasan yang ada bukan menjadi faktor untuk menghambat prestasi.

Tabel

Sarana dan Prasarana

\begin{tabular}{|c|c|c|c|c|c|}
\hline NO & Subyek & Score Hasil & Skor Max. & \% & Kriteria \\
\hline 1 & Atlet & 758 & 960 & 78,96 & Baik \\
\hline
\end{tabular}


Hasil angket pada Evaluasi Masukan (Input) komponen sarana dan prasarana PERKEMI NTT dengan 8 pernyataan angket menggunakan skala Likert yang diberikan kepada 24 atlet menunjukkan persentase
$78,96 \%$ dengan kategori baik dalam kriteria keberhasilan program.

Berdasarkan data diatas dapat digambarkan ketercapaian perekrutan atlet dalam bentuk diagram :

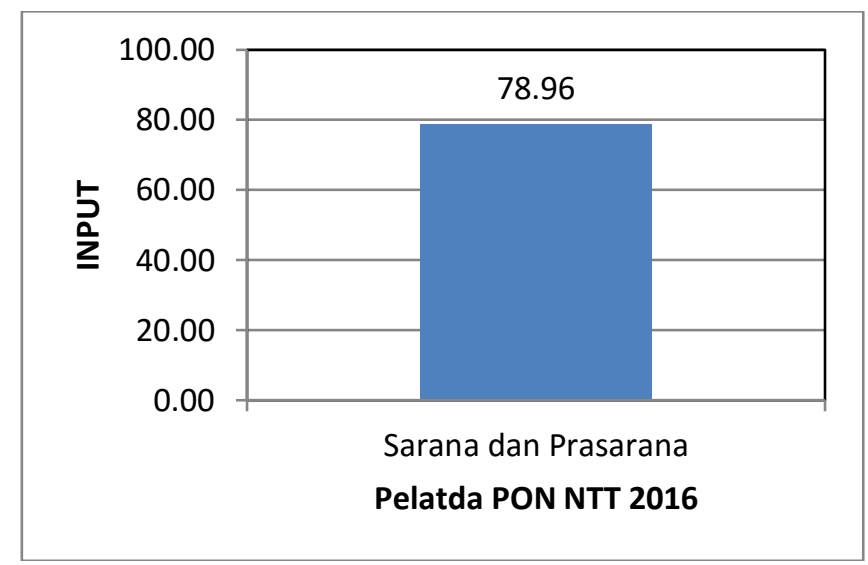

Diagram Komponen Sarana dan Prasarana

Sarana dan prasarana yang digunakan oleh PERKEMI NTT untuk melaksanakan program pembinaan PELATDA PON XIX tahun 2016 khusus cabang olahraga Shorinji Kempo belum memadai karena masih terdapat kekurangan dalam peralatan latihan fisik dan peralatan latihan tehnik.

Peralatan latihan tehnik jumlahnya terbatas dan kebanyakan dalam keadaan rusak dan masih standar nasional sedangkan yang dipakai pada pertandingan adalah peralatan dengan standar internasional. Untuk latihan fisik Pengprov PERKEMI NTT berinisiatif mengadakan peralatan yang ada disesuaikan dengan kemampuan Pengprov PERKEMI NTT.

Pemberian bantuan dari KONI tidak sesuai dengan harapan dimana waktu pemberian yang sudah dekat dengan waktu pertandingan dan peralatan yang diberikan tidak sesuai dengan permintaan Pengprov PERKEMI NTT. Untuk pemakaian gedung latihan/tempat latihan tidak terjadi masalah karena jadwal pemakaian tempat berdarkan keputusan KONI NTT untuk semua cabang olahraga yang mewakili NTT pada PON 2016.

\section{5) Penjadwalan program latihan}

Tabel

Penjadwalan Program Latihan

\begin{tabular}{|c|c|c|c|c|c|}
\hline NO & Subyek & Score Hasil & Skor Max. & \% & Kriteria \\
\hline 1 & Atlet & 1230 & 1560 & 78,85 & Baik \\
\hline
\end{tabular}

Hasil angket pada Tahapan Proses (Process) komponen Pelaksanaan Program Latihan Shorinji Kempo NTT dengan 13 pernyataan angket menggunakan skala Likert yang diberikan kepada 24 atlet menunjukkan persentase $78,85 \%$ dengan kategori baik dalam kriteria keberhasilan program.

Berdasarkan data diatas dapat digambarkan ketercapaian Pelaksanaan program latihan dalam bentuk diagram : 


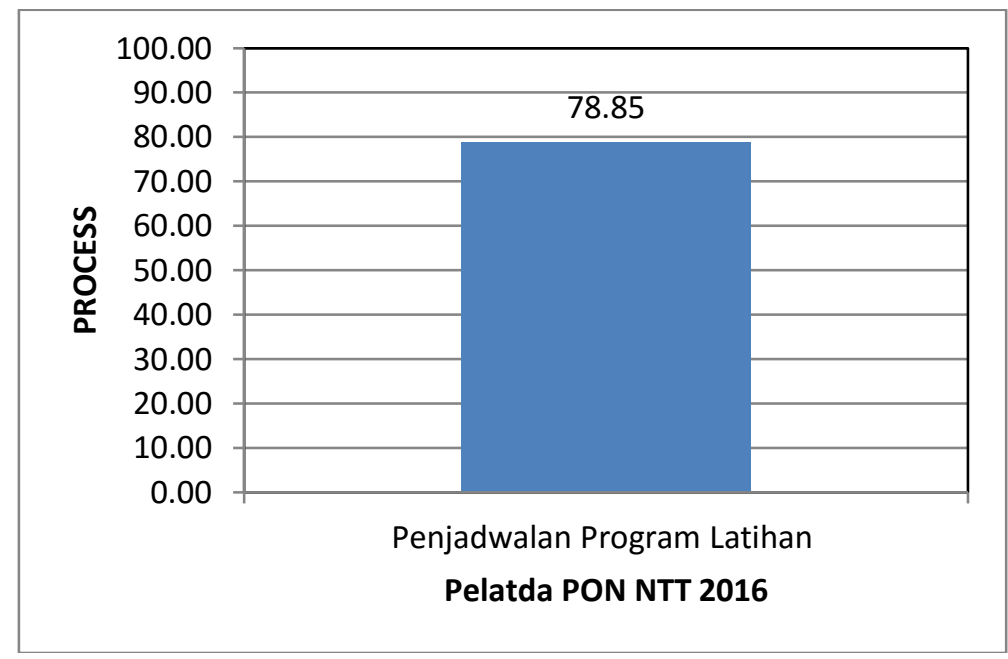

Diagram Komponen Penjadwalan Program Latihan

Penjadwalan program latihan pada PON XIX sudah ditetapkan sebelum pelaksanaan PELATDA yang terdapat dalam Buku Pedoman Pelaksanaan Latihan Terpusat Tim Shorinji Kempo NTT, sehingga pada pelaksanan wajib mengikuti penjadwalan program latihan yang telah dibuat.

Penjadwalan program latihan terdiri dari volume latihan, intensitas latihan dan frekwesi latihan. Volume latihan yang dimaksud disini adalah porsi latihan yang harus diselesaikan seorang atlet dalam satu

\section{d. Evaluasi Proses (Process)}

Evaluasi proses dalam penelitian ini terdiri dari Pelaksanaan Program Latihan dan Keefektifan Program Latihan

\section{1) Pelaksanaan Program Latihan}

unit latihan. Intensitas latihan adalah besarnya tenaga yang harus dikeluarkan dalam melaksanakan latihan tersebut dalam durasi waktu $1 / 2$ menit, 1 menit, 3 menit. Frekwensi latihan adalah beban latihan yang diberikan kepada atlet dalam bilangan hari, minggu. Latihan di NTT tidak menganut proses yang instan tetapi dengan proses panjang karena mempunyai banyak tahapan latihan yang tidak bisa dihilangkan sehingga tidak mungkin program latihan dengan waktu misalnya 9 (sembilan) bulan di singkat menjadi beberapa bulan saja.

\begin{tabular}{|c|c|c|c|c|c|}
\hline NO & Subyek & Score Hasil & Skor Max. & \% & Kriteria \\
\hline 1 & Atlet & 1653 & 2040 & 81,03 & Baik Sekali \\
\hline
\end{tabular}

Hasil angket pada Tahapan Proses (Process) komponen Pelaksanaan Program Latihan Shorinji Kempo NTT dengan 17 pernyataan angket menggunakan skala Likert yang diberikan kepada 24 atlet menunjukkan persentase $81,03 \%$ dengan kategori baik sekali dalam kriteria keberhasilan program.

Berdasarkan data diatas dapat digambarkan ketercapaian Pelaksanaan program latihan dalam bentuk diagram : 


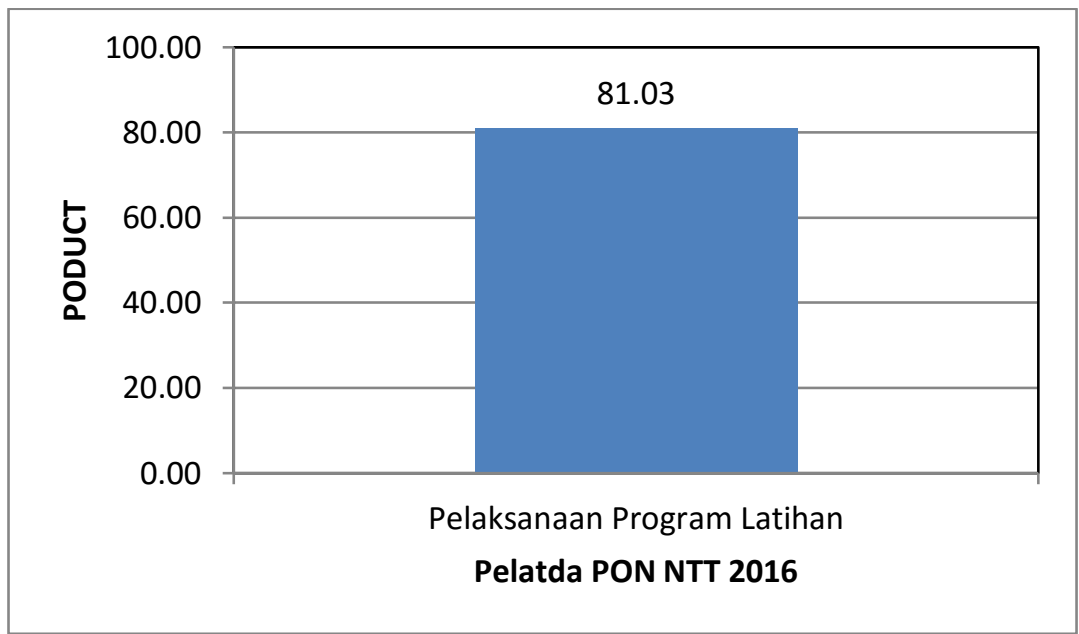

Diagram Komponen Pelaksanaan Program Latihan

Dalam proses pelaksanaan yang dilakukan oleh PERKEMI NTT dalam pembinaan program PELATDA PON dilakukan beberapa tahap yaitu bertahap, bertingkat dan berlanjut artinya beban latihan tidak boleh meningkat secara mendadak tetapi harus meningkat secara teratur dan berlanjut dikaitkan dengan daya tangkap atlet.

Pelatih dan atlet berlatih keras untuk mencapai target sesuai program, atlet juga diberikan kesempatan untuk bertanya atau menyampaikan kekurangan dan diberikan solusi oleh pelatih. Pelatih juga terus memotivasi atlet untuk berprestasi, selain itu jika atlet tidak disiplin tetap diberikan hukuman baik itu hukuman fisik maupun psikis. Pelatih juga memberikan evaluasi lewat catatan perkembangan latihan atlet sehingga atlet dapat terus membenahi yang masih kurang.

Semua tahapan ini sudah dilakukan dalam proses persiapan menuju PON akan tetapi masih ada hal yang perlu untuk dibenahi terkait pelaksanaan program latihan yaitu konsistensi waktu dimana jam selesai latihan yang terkadang melebihi jadwal yang sudah disepakati. Seperti wawancara dengan atlet yang mengatakan terkadang atlet tidak bisa belajar atau pergi ke kampus karena waktu selesai latihan yang tidak sesuai jadwal dan mempengaruhi waktu istirahat dan makan atlet.

\section{2) Keefektifan Progam Latihan}

\section{Tabel Keefektifan Progam Latihan}

\begin{tabular}{|c|c|c|c|c|c|}
\hline NO & Subyek & Score Hasil & Skor Max. & \% & Kriteria \\
\hline 1 & Atlet & 904 & 1080 & 83,70 & Baik Sekali \\
\hline
\end{tabular}

Hasil angket pada Tahapan Proses (Process) komponen Keefektifan Pelaksanaan Program Latihan Shorinji Kempo NTT dengan 9 pernyataan angket menggunakan skala Likert yang diberikan kepada 24 atlet menunjukkan persentase
$83,70 \%$ dengan kategori baik sekali dalam kriteria keberhasilan program.

Berdasarkan data diatas dapat digambarkan ketercapaian Keefektifan Pelaksanaan program latihan dalam bentuk diagram : 
Anna Yunita Gelu / Jurnal Terapan Ilmu Keolahragaan 4 (1) (2019)

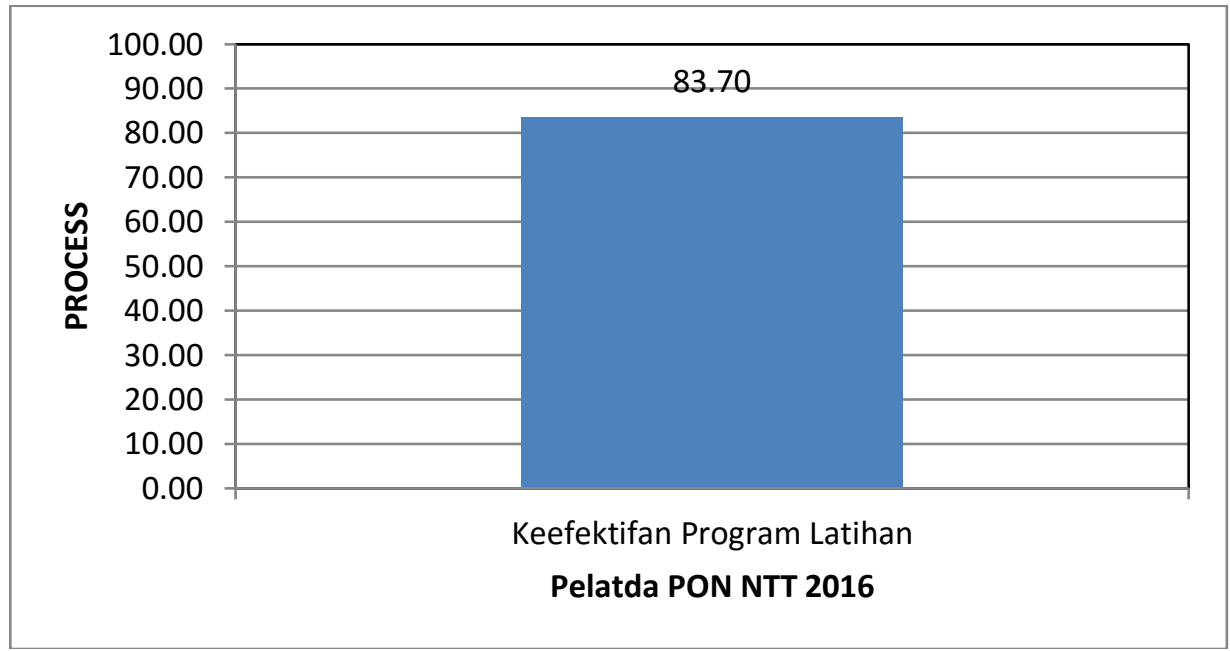

Diagram Komponen Keefektifan Program Latihan

Pelaksanaan program latihan berdampak pada peningkatan kualitas tehnik dan fisik atlet dalam persiapan dari waktu ke waktu sehingga atlet merasa siap untuk bertanding. Atlet juga telah mempersiapkan berbagai macam taktik dan strategi yang akan digunakan untuk menghadapi lawan pada saat bertanding di PON.

\section{e. Evaluasi Hasil (Product)}

Evaluasi produk dalam penelitian adalah dampak pelaksanaan program PELATDA NTT cabang olahraga Shorinji Kempo yaitu menjadi juara pada PON XIX di Jawa Barat pada tahun 2016.

\section{Tabel Evaluasi Hasil (Product)}

\begin{tabular}{|c|c|c|c|c|c|}
\hline NO & Subyek & Score Hasil & Skor Max. & \% & Kriteria \\
\hline 1 & Atlet & 526 & 600 & 87,67 & Baik Sekali \\
\hline
\end{tabular}

Hasil angket pada tahapan Hasil (Product) program pembinaan PELATDA Shorinji Kempo NTT dengan 5 pernyataan angket menggunakan skala Likert yang diberikan kepada 24 atlet menunjukkan persentase $87,63 \%$ dengan kategori baik sekali dalam kriteria keberhasilan program.
Berdasarkan data diatas dapat digambarkan ketercapaian Keefektifan Pelaksanaan program latihan dalam bentuk diagram :

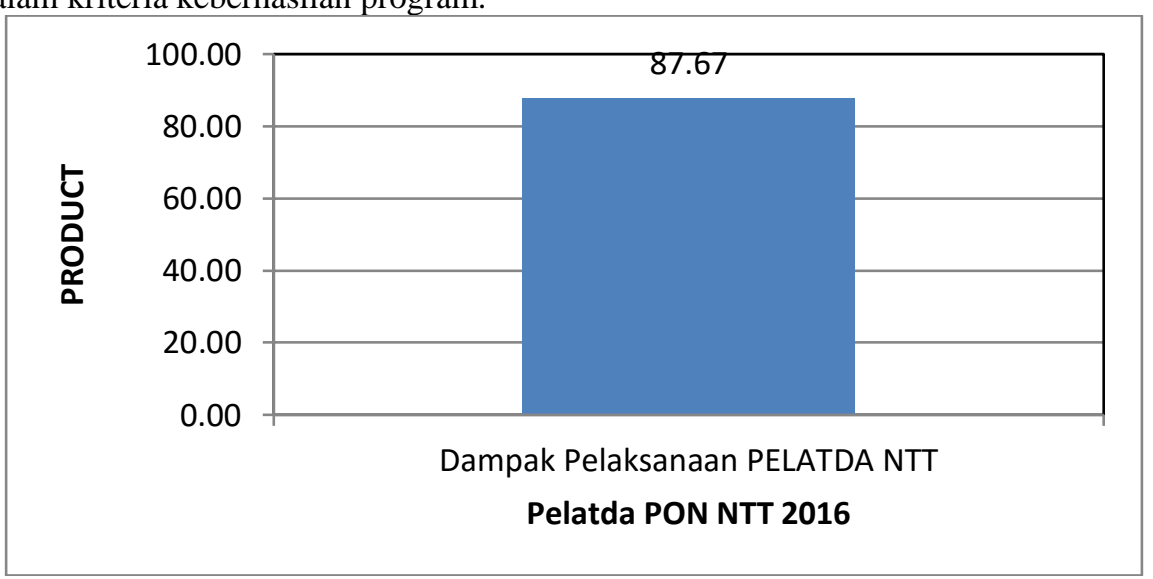

Diagram Tahapan Hasil (Product) 
Dampak pelaksanaan terhadap pembinaan program PELATDA cabang olahraga Shorinji Kempo NTT mengalami peningkatan dari PON sebelumnya yang hanya meraih 2 medali emas yang terdiri dari 1 medali emas dari nomor seni (embu) dan nomor perkelahian bebas terbatas (randori). Pada PON XIX tahun 2016 di Jawa Barat PERKEMI NTTmencetak sejarah karena untuk pertama kalinya menjadi Juara Umum pada event PON dengan meraih 7 medali emas, 1 medali perak dan 5 medali perunggu.

\section{KESIMPULAN DAN REKOMENDASI}

Berdasarkan evaluasi dengan menggunakan model evaluasi Context, Input, Process dan Product (CIPP) dari Stufflebeam menghasilkan kesimpulan sebagai berikut :

1. Context

a. Dasar pelaksanaan PELATDA PON 2016 cabang olahraga Shorinji Kempo yakni dari hasil PraPON dengan dasar hukum Keputusan Ketua Umum KONI NTT Nomor 04 Tahun 2016 tanggal 27 Januari 2016 tentang Pemusatan Latihan Daerah (PELATDA) PON XIX/2016 Jawa Barat

b. Tujuan program pembinaan PELATDA yang dibuat oleh PERKEMI NTT yaitu dapat mempersiapkan atlet NTT dengan maksimal sehingga meningkatkan prestasi dan mengangkat harkat dan martabat daerah di tingkat nasioanal (PON). Selain itu memberikan kesempatan kepada pelatih untuk menciptakan juara PON dan mendukung program kerja KONI NTT tentang pembinaan prestasi PON.

2. Input

a. Perekrutan Pelatih

Pada pelaksanaan perekrutan pelatih sudah berjalan dengan baik dan sesuai aturan pemilihan pelatih yang dibuat oleh Pengprov PERKEMI NTT yaitu dengan melihat Prestasi khususnya peraih medali pada PON, mempunyai dojo, dan aktif dalam agenda kegiatan Shorinji Kempo NTT.

b. Perekrutan Atlet
Dalam perekrutan atlet PERKEMI NTT terbuka dan bertahap yang dimulai dari kejuaraan tingkat daerah kemudian mengikuti test kesehatan dan melihat karakter/sikap atlet sendiri dalam proses menuju PON. Semua atlet diberikan kesempatan yang sama untuk bisa menjadi anggota Tim Shorinji Kempo NTT.

c. Pendanaan

Pendanaan pelaksanaan PELATDA berasal dari KONI NTT yang disesuaikan dengan PAD NTT yang kecil. Untuk memenuhi kebutuhan pembinaan yang masih kurang Pengprov PERKEMI NTT mencari tambahan dana untuk menutupi kekurangan yang ada selama proses pembinaan.

d. Sarana dan prasarana

Sarana dan prasarana dalam pembinaan PELATDA masih terbatas dan tidak sesuai dengan standar yang telah ditetapkan khususnya standar dalam pertandingan, sehingga Pengprov PERKEMI NTT berinisiatif untuk menutupi kekurangan tersebut yang disesuaikan dengan kemampuan yang ada.

e. Penjadwalan program

Penjadwalan program latihan sudah dibuat sebelum pelaksanaan PELATDA dan wajib untuk diikuti. Penjadwalan latihan terdiri dari volume latihan, intensitas latihan dan frekwensi latihan.

3. Process

a. Pelaksanaan Program Latihan

Pelaksanaan program latihan berdasarkan dengan jadwal yang sudah dibuat tetapi yang harus dibenahi adalah disiplin waktu latihan dimana saat berlatih melebihi waktu yang sudah ditetapkan sehingga atlet tidak mempunyai waktu yang istirahat yang cukup dan terkadang terlambat untuk makan.

b. Keefektifan program latihan

Atlet mengalami peningkatan dalam tehnik Shorinji Kempo dan peningkatan 
fisik, selain itu atlet juga dapat menciptakan taktik dan strategi berdasarkan kekuatan dan kelemahan yang di punya serta kemungkinan lawan yang dihadapi sehingga mempunyai gambaran apa yang dapat dilakukan pada saat pertandingan.

\section{Product}

Pada PON XIX di Jawa Barat tahun 2016 cabang olahraga Shorinji Kempo NTT menjadi juara umum dengan meraih 7 medali emas 1 medali perak dan 5 medali perunggu sehingga menjadi sejarah bagi cabang Shorinji Kempo yang baru pertama kali menjadi juara umum pada event $\mathrm{PON}$.

Sedangkan untuk rekomendasi adalah sebagai berikut:

1. Memberikan masukan ke KONI NTT dalam hal ini berkaitan dengan proses rekrutmen pelatih agar pelatih juga mengikuti test kesehatan secara umum sehingga mendapatkan hasil yang pasti tentang kesehatan pelatih.

2. Ketua PERKEMI NTT serta Kabid Binpres supaya memperhatikan serta melakukan pengawasan bagaimana pelaksanaan pembinaan PELATDA PERKEMI NTT agar dapat berjalan secara maksimal, dari setiap lini, terutama dalam proses latihan sehingga waktu latihan dan istirahat atlet berjalan konsisten.

3. Dalam penentuan asrama atlet harus memperhatikan jarak tempat tinggal dengan tempat latihan sehingga atlet tidak merasa capek sebelum berlatih.

4. KONI NTT harus menyediakan kendaraan operasional untuk Tim NTT secara umum dan Tim Shorinji Kempo secara khusus, sebab resiko berkendara cukup tinggi.

5. Pelatih, Kabid Binpres serta perwakilan atlet membuat sebuah surat atau audiensi ke KONI NTT terkait masalah perlengkapan latihan yang belum terpenuhi secara standar internasional.

6. Ketua Umum, pelatih, Kabid Binpres, Kabid Ketenagaan duduk bersama untuk membahas masalah kebutuhan tim secara menyeluruh.

7. Pengprov PERKEMI NTT bersama dengan para pelatih serta Kabid Binpres berdiskusi dengan ke KONI NTT tentang penganggaran agar dapat ditambah mengingat dana adalah faktor penting untuk penunjang prestasi dalam sebuah olahraga.

8. Kepada pelatih hendaknya selalu mengayomi dan memberikan program latihan yang sesuai kepada para atlet serta selalu mengawasi setiap jalannya latihan, serta mengawasi segala aktivitas diluar latihan. Pelatih hendaknya menanamkan nilai-nilai disiplin, tanggung jawab serta kerja sama kepada semua atlet. Pelatih juga hendaknya memanfaatkan IPTEK serta informasi informasi yang berkembang tentang dunia kepelatihan. Pelatih juga harus membuat setiap program latihan dengan benar supaya latihan dapat berjalan sebagai mana yang telah diharapkan.

9. Kepada para atlet yang terlibat didalam pembinaan PELATDA supaya berlatih dengan anjuran yang telah ditentukan oleh pelatih dan berlatih dengan giat supaya target yang ingin dicapai dapat diraih. Atlet juga hendaknya tidak selalu mengeluh dengan program latihan yang telah diberikan dan selalu berdiskusi dengan pelatih apabila ada kendala yang dialami pada saat latihan.

10. Pemerintah melalui KONI menyiapkan Pelayanan atau Asuransi Kesehatan kepada atlet baik itu selama proses persiapan PON maupun setelah selesai PON minimal satu bulan setelah PON sehingga atlet mempunyai kepastian kesehatan setelah pelaksanaan PON.

\section{DAFTAR PUSTAKA}

Arikunto. Suharsimi dan Cepi Safruddin Abdul Jabar. (2009). Evaluasi Program Pendidikan. (Jakarta : Bumi Aksara).

James Tangkudung. (2006). KEPELATIHAN OLAHRAGA "Pembinaan Prestasi Olahraga". (Jakarta : Cerdas Jaya). 
Miftah Toha. (2010).Ilmu Administrasi Publik Kontemporer. (Jakarta : Kencana Prenada Media Group).

Saburi Musa. (2005). Evaluasi Program Pembelajaran dan Pemberdayaan Masyarakat. (Bandung: Y.Pin. Indonesia).

Sugiyono. (2012). Metode Penelelitian Penelitian Kuantitatif Kualitatif Dan R\&D. (Bandung : CV Alfabeta),

Undang-undang Nomor 3 Tahun 2005 tentang Sistem Keolahragaan Nasional, Kementerian Pemuda dan Olahraga Republik Indonesia. 